\title{
BLENDED LEARNING IN TEACHERS' PREPARATION FOR THE ASSESSMENT OF ESSAY TESTS IN THE STATE PART OF THE MATURITA EXAM
}

\author{
Dana Vicherková, Josef Malach and Milan Chmura \\ Department of Education and Adult Education \\ University of Ostrava, Frani Sramka 3, Ostrava, the Czech Republic, 70900
}

\begin{abstract}
The study reflects the process of preparation of assessors and central assessors assessing the essay tests from the Czech language and literature (CLL) used in the state part of the maturita exam (secondary school leaving exam) in the Czech Republic. Using the Focus Group method, we obtained interesting and operationally useful findings about opinions from course participants on the given functions in the process of the maturita exam, time required for the online preparation, number of compulsory online assessed essay tests in the process of calibration, entire concept of the preparation and effectiveness of the online preparation.
\end{abstract}

\section{KEYWORDS}

Blended Learning, e-Learning, Assessor, Essay Test, Maturita Exam

\section{BLENDED LEARNING IN TEACHER EDUCATION}

"Blended learning, also referred to as hybrid learning, combines the best features of traditional schooling with the advantages of online learning to deliver personalized, differentiated instruction across a group of learners. Students in formal blended learning educational programs learn online part of the time, yet have the benefit of face-to-face instruction and supervision to maximize their learning and to best fit their own needs" (Powell et al., 2015a, p. 5).

Blended learning may fall into four basic models: Rotation model (with variants: rotation, lab rotation, flipped rotation and individual rotation), Flex model, A La Carte model and Enriched Virtual model (Powell et al., 2015).

The Enriched Virtual model is "a course or subject in which students have required face-to-face learning sessions with their teacher of record and then are free to complete their remaining coursework remotely from the face-to-face teacher. Many Enriched Virtual programs began as full-time online schools and then developed blended programs to provide students with brick-and-mortar school experiences. The Enriched Virtual Model differs from the Flipped Classroom Model because in Enriched Virtual programs, students seldom meet face-to-face with their teachers every weekday. It differs from a fully online course because face-to-face learning sessions are more than optional office hours or social events; they are required."

E-learning as a component of blended learning is usually carried out as distance learning. According to Seaman, Allen and Seaman (2018), distance learning uses one or more technologies to deliver instruction to students who are separated from the instructor and to support regular and substantive interaction between the students and the instructor synchronously or asynchronously. Technologies used for instruction may include the following: Internet; one-way and two-way transmissions through open broadcasts, closed circuit, cable, microwave, broadband lines, fibre optics, satellite or wireless communication devices. According to the authors, the distance between the providers of distance courses and students does not have to be big. In 2007, more than half of students studied within 50 miles from the campus and in 2016, already $56.1 \%$ of students studied in the same American state where the providing educational institution is situated. 
Midgley (2015) offers an interesting look at distance learning in Great Britain when he argues that "distance learning is a way of learning remotely without being in regular face-to-face contact with a teacher in the classroom. In recent years the advent of the Internet and widespread use of the computer has led to a huge growth in distantly delivered tuition and study. At undergraduate level distance learning usually means students engaging with learning materials at home or work. These materials are produced by the university, college or learning provider and are either sent directly to the student or more usually today accessed via the Internet. Tutorial support is provided via a virtual learning environment, telephone, email or other electronic means. There may be occasional face-to-face encounters with tutors and attendance at week-long summer schools". Midgley further specifies the advantages and disadvantages - why to choose distance learning. The main advantage of distance learning is that it allows you to fit your learning around your work and home life. You can also usually set your own pace of study. It is your decision as to when and where you study. The downside is that you will not enjoy the conviviality of being on campus and rubbing shoulders with fellow students on a daily basis. Loneliness and feelings of isolation should be avoided, however, by frequent online contact with tutors and taking part in virtual forums, virtual help groups and discussion rooms. Distance learning providers usually offer dedicated support to their online or distance learning students.

There are not many studies analysing the use of blended learning in teacher education. Nonetheless, when Shand and Farrelly (2017) were examining the use of blended learning for teacher instruction in such a way, they "found that clear organization and structure lead to optimal learning conditions; transparency and support facilitated student understanding of course expectations; community and discourse helped students learn from their peers; and the opportunities for personalized learning provided students some choice in how, where, and what they learned. The students in the course learned many valuable lessons regarding principles and best practices of blended instructional design and implementation". After the analysis of hundreds of sources, Torrisi and Drew (2013) point out that "The design and provision of much needed professional development and support, aimed at fulfilling the promise of blended learning in higher education through the integration of technology, transformation of practice and subsequent widespread use of effective blended learning practices evidently still requires significant scholarly research". Powell et al., (2015b) created Blended Learning Teacher Competency Framework, which identifies 12 specific competencies, which are organized into 4 larger domains - mindsets, qualities, adaptive skills, and technical skills. These domains differ not only in content (the type of competency and how is it expressed) but also in how they are developed in individuals.

\section{THE CONCEPT OF THE NEW MATURITA EXAM IN THE CZECH REPUBLIC}

The concept of the new maturita exam has been carried out in the Czech Republic since 2011. Its compulsory part has always been an exam from the Czech language and literature (CLL). As a second compulsory subject, secondary school pupils can choose either mathematics or a foreign language. However, the concept of the maturita exam has not been settled yet - the state trying to promote a compulsory mathematics exam despite the opposition of many representatives from secondary schools. In 2018/2019, the state maturita exam in CLL consisted of three parts: essay test in the CLL, didactic test and oral exam. Each part has a predetermined weight in a precisely defined order, for the CLL it is 1:1:1 (Vicherkova, 2018). Successful completion of all three parts according to predetermined criteria (by CERMAT) is a necessary condition for passing the complex maturita exam in the CLL.

The essay test is assigned centrally by CERMAT, with a choice between six topics. The time for writing the essay is 110 minutes; the minimum number of words in the text is 250 .

\section{EDUCATION OF ASSESSORS OF ESSAY TESTS IN THE CZECH LANGUAGE AND LITERATURE USING BLENDED LEARNING}

Students' essay tests are assessed by central assessors. They are experienced CLL teachers from secondary schools who are trained for this by passing two courses (basic and extended), which last more than 50 hours in 
total. The course for beginning central assessors is not opened by CERMAT every year, nevertheless, a compulsory refresh training for central assessors takes place every year.

Two subjects managed by the state participate on the training of assessors - Centrum pro zjištováni výsledku vzdélávání, Centre for Detection of Education Results (CERMAT, 2019) and Národní institut pro dalši vzdèlávání, National Institute for Further Education (NIDV).

The basic preparation of assessors consists of two essential parts: e-learning and face-to-face learning. E-learning conducted in LMS CERMAT (CISKOM) (Learning Management System) always precedes face-to-face learning. The preparation consists of compulsory and recommended learning modules. A learning module is an item in online learning which deals with one topic designated for assessors' study. Important compulsory modules are concluded with an online test. After completion of the e-learning part, the LMS CERMAT system allows participants to print a certificate before they start the face-to-face part of the training. The advantage of this teacher training is that all successful participants can register to get unlimited access to all learning modules in the electronic form in the e-space of the LMS library available at http://knihovnalms.cermat.cz.

A real, functioning group of assessors are so-called central assessors who successfully complete the basic course for beginning assessors and then the extended course for central assessors. They can start to prepare for this higher-level function after successful completion of the basic training for assessors. A period of one year at minimum usually elapses between the training for these two functions. The preparation of central assessors consists of an e-learning part (i.e. e-assessment of three packages where each contains 20 essays) and a face-to-face part, which is completed by an exam. The function of a central assessor is performed by approximately four thousand teachers of the CLL in the Czech Republic. Their work is managed by approximately 20 team leader assessors and these are managed by four subject leader assessors and one subject manager assessor is in charge of the whole team of assessors in CERMAT. During the e-study, central assessors upload assessment records of 60 selected essays in the CLL into the LMS CERMAT system. The aim of their training is the calibration of assessments, which is achieved by assessors' intensive skill training so that they are able to assess selected essays according to a precise set of rules. During the e-training as well as the face-to-face meetings, central assessors are informed of results of their assessment according to a set standard and the form of feedback is determined in advance. Nevertheless, not all teachers receive a certification to perform the function of a central assessor. Table 1 clearly demonstrates the preparation of both types of assessors, including the proportion of the e-learning parts (in online mode) and their duration.

Table 1. System of Essay Assessors' Preparation (own source)

\begin{tabular}{|c|c|c|c|c|c|c|}
\hline $\begin{array}{l}\text { Teacher's } \\
\text { function in } \\
\text { the system of } \\
\text { the maturita } \\
\text { exam }\end{array}$ & $\begin{array}{l}\text { Course } \\
\text { name }\end{array}$ & $\begin{array}{c}\text { Course } \\
\text { components }\end{array}$ & $\begin{array}{l}\text { Duration } \\
\text { (in } \\
\text { hours) }\end{array}$ & Authorisation & $\begin{array}{c}\text { Form of } \\
\text { certification }\end{array}$ & Note \\
\hline $\begin{array}{l}\text { Beginning } \\
\text { assessor }\end{array}$ & Basic & $\begin{array}{l}\text { Online learning } \\
\text { Face-to-face } \\
\text { learning }\end{array}$ & 9 & $\begin{array}{l}\text { Only access to course } \\
\text { materials and use of } \\
\text { knowledge when } \\
\text { teaching pupils at } \\
\text { secondary schools }\end{array}$ & $\begin{array}{l}\text { Certificate on } \\
\text { completion of } \\
\text { the course } \\
\text { with lifetime } \\
\text { validity }\end{array}$ & $\begin{array}{l}\text { Proposition to } \\
\text { participate in the } \\
\text { course is submitted } \\
\text { by the school } \\
\text { principal }\end{array}$ \\
\hline \multirow{2}{*}{$\begin{array}{c}\text { Central } \\
\text { assessor }\end{array}$} & Extended & $\begin{array}{l}\text { Online assessment of } \\
\text { three packages of } \\
\text { essays } \\
\text { Face-to-face } \\
\text { calibration } \\
\text { discussion }\end{array}$ & 20 & $\begin{array}{l}\text { To assess essays for a } \\
\text { certain period of time }\end{array}$ & $\begin{array}{l}\text { Certificate of } \\
\text { the central } \\
\text { assessor }\end{array}$ & $\begin{array}{l}\text { Extended course } \\
\text { can be only } \\
\text { attended after the } \\
\text { completion of the } \\
\text { basic course }\end{array}$ \\
\hline & Refresh & $\begin{array}{l}\text { Online assessment of } \\
\text { three packages of } \\
\text { essays }\end{array}$ & 20 & $\begin{array}{l}\text { To assess essays in the } \\
\text { following period of time }\end{array}$ & $\begin{array}{l}\text { Extension of } \\
\text { the certificate } \\
\text { validity for a } \\
\text { certain period } \\
\text { of time }\end{array}$ & $\begin{array}{l}\text { Course can be only } \\
\text { attended after the } \\
\text { completion of the } \\
\text { extended course }\end{array}$ \\
\hline
\end{tabular}




\section{THE STUDY OF ESSAY ASSESSORS' OPINIONS ON THE EFFECTIVENESS AND PERSPECTIVES OF BLENDED LEARNING}

\subsection{Research Aims}

At the beginning of 2019, the study authors did a survey among assessors assessing the essay tests in order to find out what trained teachers think about a) the time required for the e-learning part of the blended learning; b) the quantity of essays assessed in the e-learning assessment; c) the whole concept of the e-learning preparation; d) the effectiveness of the e-learning preparation.

\subsection{Method}

A group discussion using the Focus Group method with 5 - 6 trained people who took fictitious names in order to ensure anonymity. The discussions took place three times. They were moderated by two researchers. The Focus Group was carried out according to a pre-prepared scenario, which ensured that the discussion of the problem moved from more general questions towards the focal point. With participants' agreement, we recorded an audio recording of the discussion.

\subsection{Research Sample}

The research sample consisted of 18 teachers of the CLL from secondary schools in the Moravian-Silesian region in the Czech Republic who participated in the training (or in the improvement, the so-called refresh training) for the function of an assessor or central assessor of essay tests in the state part of the maturita exam in the CLL. Groups of respondents were homogenous in terms of their subject specialisation in the CLL.

\subsection{Results}

In accordance with the four research aims, the results are divided into four parts. In accordance with the accepted qualitative research methodology, the results are presented in form of excerpts from teachers' authentic testimonies.

\subsubsection{The Time Required for the e-Learning Preparation}

Eva: "As for the time, I managed to do the modules 3.1.1 and 3.1.2 without problems. I successfully completed this form of online learning by scoring 9 and 10 in the tests. However, I spent more time assessing given essays in e-learning for the role of a central assessor (at the beginning, I was correcting one essay for 30 minutes on average)."

Jan: "I completed the compulsory modules in the online learning with tutor's participation in 10 days, I successfully completed each module with a test. I view online learning for this role as very time-demanding and financially undervalued."

Veronika: "As for time, I managed to do e-learning for the role of an assessor in three days (without a tutor whom I actually didn't need). Electronic assessment of essays was a challenge for me and exhausting because of the required time."

Hana: "Online learning (as well as face-to-face learning) for the role of an assessor and for the role of a central assessor was a useful experience for me of how to effectively use time which I spend on the assessment of pupils' texts. I learnt how to organise my time when correcting essays better. Similarly, I don't view the annual refresh course for the role of a central assessor as time-demanding."

Renata: I think that CERMAT should inform the teachers at secondary schools (who prepare students for the maturita exam but are not active central assessors) more openly about changes in the assessment methodology and send materials for the new methodology of text assessments to schools."

Ivana: "The basic course for the role of an assessor (online form) wasn't very time-demanding; I managed to complete all the tests in two days. I think that there should be a difference between those who enter the system of the central essay assessment for the first time and those who have been correcting texts for a longer 
time (three and more years). As for beginning assessors, I don't think the time organisation of the course should change. As for more experienced assessors, I would reduce the number of essays for correction to half, this would save time."

Petr: "I think that the basic course for the role of a beginning assessor in the e-learning is timely, well-organised and as for the online course for the role of a c-assessor, I would reduce the number of compulsory essays for correction from 60 to 45, this would save time. And in the refresh course, the assessor should compulsorily assess only 15 essays, this would be more time and training effective."

František: "I don't see the online course for the role of an assessor as time-demanding. The online course for the role of central assessors is more demanding, especially the e-learning assessment of 60 essays.

Zuzana: "The course for the role of a beginning assessor was less time-demanding. Next part of the course for the role of a c-assessor was very time-demanding since it reflected many changes in the approach to the assessment of given texts."

Karla: "I understand that if I apply for a course, I will complete it no matter the time. Nonetheless, I view the annual repetition of the refresh course for the role of a central assessor as useless (once in two years would be enough)."

Summary a): The participants of the online course for the role of an essay assessor viewed the time required for the e-learning preparation as suitable, sufficient, and relevant to the course content and aim. The online course for the role of a central assessor was very time-demanding for the participants. The refresh part of the online course was time-ineffective, lengthy, and formal.

\subsubsection{The Quantity of Essays Assessed in the e-Learning Assessment}

Jan: "I would reduce the number of compulsory e-assessed texts in the compulsory cyclic assessment of selected essays (to approximately 25-30 essays) for a central assessor."

Katka: "I would also reduce the number of compulsory assessed essays for central assessors, if the cyclicality is implemented in the training of central assessors, for example also after the course. My suggestion is 30 essays (in the annual refresh training)."

Iveta: "I recommend to include more productive tasks in the course and then to use these texts in e-learning as a database of examples for the text assessment. To assess a certain number of essays in the training is very important to maintain the competence of a central assessor. The assessor also revises rules and reads the criteria for the assessment in this refresh training. I suggest that even non-central assessors be able to practise the assessment of a certain number of essays in the online LMS environment."

Hana: "Teachers are certainly used to correct a large number of texts under stress. The stress when assessing texts in the maturita exam is always there, it depends on how we organise our time and the number of essays to assess in order to be fine."

Ivana: "Experienced central assessors correct around 200 essays online every year in April, then they assess 30 texts in the refresh training during November, December and January. And then in April again, around 200 essays, which is very burdensome. I suggest that experienced c-assessors correct only 30 essays in the refresh training."

Eva: "I don't like assessing such a large number of essays compulsorily for the role of a central assessor in the refresh training. I assess around 180 essays in the real assessment, this is all right, every assessor can choose how many essays they will correct."

Summary b): Different opinions on the number of essays for the compulsory e-assessment formed among discussion participants for the role of a basic assessor and central assessor. In the online course for the role of an assessor, the participants would appreciate more authentic texts for the training of assessment of problematic elements with immediate feedback from a course tutor. On the other hand, central assessors would agree to reduce the number of compulsory assessed essays to 30, instead of current 60 essays in the course as well as in the refresh compulsory cyclical assessment of texts.

\subsubsection{The Whole Concept of the Online Preparation}

Jarda: "I see the concept of e-learning for the role of an assessor as a good idea of how to assess essays from the perspective of functional stylistics. Nonetheless, I would simplify the system of essay assessment." 
Veronika: "I would loosen the system, it's too rigid, for example, it doesn't correspond with the so-called mixed functional styles. I recommend being more open, discussing with teachers in practice and educating assessors already at universities."

Jarda: "I agree with this opinion."

Pavel: "To assess a text only from the perspective of functional stylistics is, in my opinion, a unilateral approach. I would focus more on the assignment of mixed styles."

Eva: "I respect the set system and rules. However, exceptions in the assessment of texts should be allowed. I find the concept of e-learning for the role of a beginning assessor very good. I would simplify the concept of e-learning for the role of a central assessor, though. I would create more space for discussion and respect the professional argumentation form 'the bottom' from central assessors. I would reduce the directiveness in the control activities by Cermat, especially from the subject leader assessors. I would also change the content of some assessing criteria in the system of the text assessment. It makes no sense that writing commas is in the criterion $2 \mathrm{~A}$, which primarily deals with spelling mistakes in the text (punctuation should be part of $3 \mathrm{~A}$, which deals with the sentence structure). As a mother of small children, I don't like doing e-learning at exactly specified times, I see it as a discriminatory factor in education."

Jaroslava: "The system of training for the essays assessors in the Czech language is quite good, but there should be space for the development of changes in accordance with current conditions, needs, which are not presented until the direct text assessment in real maturita exams. I would educate all teachers of Czech more, including teachers at primary schools. I would also introduce a course for the text assessment at universities specialising in the education of Czech as well as in other subjects."

Jan: "The online course for the function of a beginning assessor is illustrative and formally well-arranged. The feedback from tutors (lecturers) on the assessment of individual essays should be faster, more specific, more detailed, not just general statements saying that one of the central assessors usually overvalues texts (I recommend that tutors explain the errors more specifically in the essay assessment from a professional point of view)."

Renata: "I would suggest more openness and richness in outputs from each year of the central essay assessment. That is to say that CERMAT should inform teachers at schools about changes in the text assessment, which are based on the dynamics of the civil society, for example from professional discussions about problematic essays, from reports and pupils' appeals when they don't agree with the given assessment of their essay and others. If CERMAT makes updates in the methodology of essay assessment, all Czech language teachers at secondary schools should know about it, to open the system of essay assessment not only to central assessors but to the wider teaching public."

Summary c): The discussion participants view the concept of e-learning for the role of assessors as successful, however this does not apply to the dogmatic following of CERMAT rules. The e-learning trainees suggest introducing more flexibility and wider standard for the assessment of problematic elements in the central assessment of texts. The central assessors view the concept of the course for the role of a c-assessor as adequate, but they would welcome the reduction in the number of compulsory assessed essays and choice of texts in the training for the central assessment. They often see assessor leaders' commentaries in the online environment in the refresh training as formal, devoid of information and delayed.

\subsubsection{The Effectiveness of the e-Learning Preparation}

Hana: "The most professional communication in the online environment (with the course tutor and team leader assessor) is during the assessment of the real maturita exam."

Renata: "I commend the communication with tutors, I was always met with a professional attitude in communication, tutors are willing to understand young people's lifestyle, which is reflected in assessed texts. I see more dominance and maladjustment in opinions of subject leader assessors."

Ivana: "During the real text assessment of the maturita exam, the online communication with a tutor is always great and effective. However, the basic online course for the role of an assessor was very unsuitable for me because I have small children and I wasn't able to finish the online course with the participation of a tutor within the time limit. As for the training for central assessors, in the feedback in form of a table, the most important data are those in which all assessors generally deviate the most from the set standard, the other feedback regarding the results of the text assessment is formal and useless." 
Yvona: "The whole system of the maturita exam in Czech seems like a formality to me, and I am saying it from the perspective of my teaching experience at secondary grammar school. The level of the maturita exam in the Czech language and literature is easy for students at secondary grammar schools. Nonetheless, I understand that the change in the whole concept of the maturita exam was necessary. The required level of pupils' knowledge should increase, though. I see the advantage of e-learning in the open access to up-to-date information, not only for the trainees during the course but also for those who already finished the course."

František: "In the basic course for assessors, the communication with the tutor was more personal, good, with expert knowledge. In the online course for central assessors, I was met with more directiveness from the team leaders and especially subject leaders. I had to re-assess my essay assessment twice according to Cermat instructions (it means through communication with a team leader assessor who received instructions from a subject leader assessor). The third time, I stuck to my assessment; I didn't re-assess the problematic text. I couldn't talk about the quality of my work right after my assessment, professional interactive communication regarding certain elements was lacking, in other words, good-quality feedback from a tutor was missing."

Petr: "I would recommend opening the e-learning for the role of an assessor to a wider group of CLL teachers (to all teachers at secondary schools), LMS is an economically effective environment. It would be also useful to give access to the online course and LMS CERMAT (CISKOM) environment to all teachers, where they can access methodology documents, manuals for the assessment, scales for the criterion essay assessment and others. Teachers of Czech could study by themselves using the pleasant environment of the e-learning. The communication with a tutor was always without problems."

Katka: "I don't communicate with tutors, but I check whether the online system accepted my assessed essays. I already understand the text e-assessment quite well; I don't need to meet other assessors and CERMAT representatives in the refresh training to assess essays."

Summary d): The discussion participants clearly stated that the e-learning for the role of an assessor partly made the preparation of essay assessors more effective. They also confirmed that the e-learning system is well-designed, however, it is also dependent on participants' activity, whether they ask, discuss with a tutor, think about possible solutions together, open group discussions across roles, which the LMS CERMAT system enables. They speak rather well of tutors' role in the basic course for the role of an assessor. Discussion participants have more critical comments on the training for central assessors and insufficient e-communication between CERMAT and future central assessors when providing feedback on the quality of essay test e-assessment. They also noticed an excessive criticism of central assessors' work from subject leader assessors in the real text assessment during the maturita exam period. On the other hand, they spoke well of the electronic communication (professional competence and subject expertise) from team leader assessors towards central assessors.

\subsection{Discussion}

The authors are not aware of studies which would examine the use of blended learning in the preparation of beginning and central assessors assessing essay tests in the CLL. Authentic testimonies acquired using the Focus Group method are usable for the formulation of items for a broad interview survey. Its aim is to gain valid feedback for the implementation of an e-learning preparation of assessors, and to evaluate whether it fulfils theoretically formulated potentiality of blended learning.

\section{CONCLUSION}

The advantages of e-learning for the function of a beginning and central assessor are: unlimited access to up-to-date information during and after the course, economic efficiency (minimum costs), teachers' motivation to lifelong learning, time efficiency in the learning process according to one's own plan, dynamic growth of information, standardisation in the knowledge apparatus, accessibility of study materials, option to communicate in a group, great option to communicate with a tutor, administrator or regional NIDV guarantor, simplicity, comprehensibility, clarity of the LMS CERMAT, CERTIS, well-designed study materials, accessible and professional technical support provided by system administrators, tutors and team leader 
assessors' expertise and effective communication (especially during the real essay assessment in the maturita exam in the CLL) and others.

The disadvantages of e-learning for the function of a central assessor are: time delay in the communication with a tutor, problems with technical devices, indirect contact with a lecturer, estrangement of the virtual environment, room for insufficient self-discipline and infrequency of studying, financial costs for the creation of courses, no access for teaching public (except for course participants), directiveness in comments of several leaders (e.g. subject leader assessors, delayed feedback of the text assessment results in the training for the role of a central assessor as well as in its refresh training).

Participants of the blended learning course for the role of an assessor and central assessor suggest introducing more flexibility into the central essay assessment and wider standard for the assessment of problematic elements, they also suggest adjusting one criterion in the assessment of given elements (i.e. not to mix spelling, syntactic and lexical and morphologic mistakes).

Some assessors suggest training wider teaching public in the methodology for the text assessment (e.g. already during university studies) with the possibility to share experience with a text assessment not only during the training and the maturita exam itself.

Women aged 35 and under suggest setting nonlimiting time conditions of the e-learning with tutor's presence for the role of a beginning assessor (not only for 14 days).

\section{REFERENCES}

Allen, I. E., Seaman J., 2015. Grade Level: Tracking online education in the United States. Babson Survey Research Group, Quahog Research Group, LLC. [online] http://www.onlinelearningsurvey.com/reports/gradelevel.pdf (accessed 4 November, 2015).

CERMAT, 2019. Koncepce maturitní zkoušky 2017/2018. [online] http://www.novamaturita.cz.

Midgley, S., 2018. What is Distance Learning? [online] at http://www.thecompleteuniversityguide.co.uk/distancelearning/what-isdistance-learning/ (accessed 4 November, 2018).

Powell, A. et al., 2015a. Blending Learning: The evolution of Online and Face-to-Face Education from 2008-2015. iNACOL, 2015.

Powell, A. et al., 2015b. iNACOL Blending Learning Teacher Competency Framework. iNACOL. [online] at http://www.inacol.org/resource/inacolblended-learning-teacher-competency-framework/ (accessed 8 January, 2019).

Seaman, J. E., Allen, I. E., Seaman, J., 2018. Grade Increase: Tracking Distance Education in the United States. Babson Survey Research Group, Pearson, Online Learning Consortium, Tyton. [online] at https://onlinelearningsurvey.com/reports/gradei ncrease.pdf (accessed 10 January, 2019)

Shand, K. and Farrelly, S. G., 2017. Using Blended Teaching to Teach Blended Learning: Lessons Learned from Pre-Service Teachers in an Instructional Methods Course. Journal of Online Learning Research, 3(1), 5-30.

Torrisi, G. and Drew, S., 2013. The literature landscape of blended learning in higher education: the need for better understanding of academic blended practice. International journal for academic development, 18 (4), 371-383. https://doi.org/10.1080/1360144X.2013.786720.

Vicherková, D. 2018. Maturitní zkouška v očekávání a realitě současnosti. In Diagnostika výsledků vzdělávání a rozvoje klíčových kompetencí. Monografie. Ostrava: Ostravská univerzita, PdF, 23-35. ISBN 978-80-7599-025-9. 